\title{
Relationship Of Mother Factors With Low Birth Weight (LBW) Infants Which Are Treated In DR.M. Djamil Central Public Hospital Padang
}

\author{
NovelaDelfita $^{1 *}$, Desmiwarti $^{2}$, MeilindaAgus $^{3}$ \\ ${ }^{1}$ Bachelor OfMidwifery Program FK-UNAND, JlnNiaga No.56 Padang City, 25127, Indonesia \\ ${ }^{2}$ Bachelor OfMidwifery Program FK-UNAND, JlnNiaga No.56 Padang City, 25127, Indonesia \\ ${ }^{3}$ Bachelor OfMidwifery Program FK-UNAND, JlnNiaga No.56 Padang City, 25127, Indonesia
}

\section{SUBMISSION TRACK \\ Recieved: Oktober 272017 \\ Final Revision: Nopember 02, 2017 \\ Available Online: 15 Desember 2017}

KEYWORDS

LBW, Mother factor

CORRESPONDENCE

Phone: 082174504808

E-mail: noveladelfita10@gmail.com

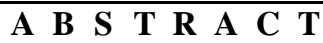

Low Birth Weight (LBW) is an infant born with a weight less than 2500 grams. LBW is one of the causes of the high rate of morbidity and infant mortality, and the low quality of human resources. The occurrence of LBW is related to the condition of the mother during pregnancy. This study was aimed to determine the factors associated with the occurrence of LBW.

This was a qualitative study with case control study design. The subject of the study was the mother of the LBW infant being treated at Dr. M. DjamilCentral Public Hospital Padang as many as 36 respondents (cases), and mothers of infants who were treated with other diseases as much as 36 respondents (control) from July to mid September 2017 taken by Consecutive Sampling. Data collection was done by filling out questionnaires, observation of medical record data, and measurement of upper arm circumference. Data were analyzed univariate by using frequency distribution and bivariate using chi square test with the degree of meaning $5 \%$ ( $\mathrm{p}$-value $=<0,05)$.

The result of the analysis showed that there was a correlation between maternal age at risk with LBW infants, there was a relationship of poor mother's nutritional status with LBW infants, there was a parity relationship of primiparous mother with LBW infant, there was a relationship of mother who suffered one or more medical illness with LBW infant, there was no relationship of gestational distance to LBW infants, and there was a tendency for the relationship between gemelli gestation and LBW infants.

Maternal age, maternal nutritional status, parity, and maternal medical illness are associated with LBW infants treated in Dr. M. Djamil Padang. Regular and periodic monitoring and examination of pregnancy is important to prevent the baby from being born with LBW. 


\section{INTRODUCTION}

Low Birth Weight (LBW) is an infant born with a birth weight of less than 2,500 grams.LBW infants have a lot of risk of various problems in the body system due to unstable body condition.Infants who can not survive will face the risk of death, thus causing high infant mortality (IMR). While babies are able to survive, most infants tend to have impaired immune function, increased risk of disease / health problems, nerve damage, malnutrition, reduced muscle strength, or low levels of intelligence (low cognitive and IQ abilities) which will affect the quality of human resources (Ministry of Health RI, 2014; UNICEF, 2016).

The occurrence of LBW is associated with gestational age that is not enough months (premature) and dismaturitas.Is Premature babies born at gestational age less than 37 weeks.Dysmaturity is a baby born just months, but the birth weight is smaller than the period of pregnancy, which does not reach 2,500 grams.However, the most common cause of LBW is preterm delivery (IDAI, 2013).

The causes of LBW are influenced by various risk factors. These factors include maternal factors such as maternal age;parity;nutrition;medical illness, fetal factors such as chromosomal / genetic abnormalities;gemelli;gender;congenital

abnormalities, placental factors, socioeconomic, and environmental (Fraser and Cooper, 2009; IDAI, 2013).

LBW is not only a major predictor of prenatal mortality and morbidity, but some studies have found that LBW increases the risk of non-communicable diseases such as diabetes and cardiovascular disease in later life (WHO, 2014). This incident is closely related to the quality of human resources.According to data from the Human Development Index (HDI), Indonesia in 2015 is ranked 110th out of 187 countries, with an index of 0.684 compiled by UNDP's United Nations Development Program (UNDP, 2015).

Every year newborn or neonatal deaths reach $37 \%-45 \%$ of all deaths in toddlers. The majority of all infant deaths, about $75 \%$ occur in weeks first life and between $25 \%$ -

$45 \%$ Dead the occurs within the first 24 hours of life.The main cause of death newborn baby or neonatal in this world amongother things is prematurity andBBLR 29\%, sepsis and pneumonia $25 \%$, asphyxia and trauma $23 \%$.LBW ranks first as the cause of infant mortality in the world in the early period of life, because babies born with weight less than 2,500 grams are very susceptible to infection (WHO, 2012; 2016).

According to Indonesia Health Demography Survey 2012, infant mortality rate in Indonesia reached 32 per 1000 live births.Results of the Intercensal Population Survey 2015 shows an IMR of 22,23 per 1,000 live births (Ministry of Health RI, 2016).Based on data Riskesdas 2013, the percentage of children under five (0-59 months) with LBW in Indonesia is $10,2 \%$.LBW percentage is highest in Central Sulawesi province $(16,8 \%)$ and the lowest in North Sumatra (7.2\%), while the percentage of LBW in West Sumatra which is about 7.4\% (Ministry of Health RI RI, 2015).

Infant mortality rate in West Sumatra has decreased, although the target province only reached 66\%.AKB in West Sumatra in 2012 is 27 per 1000 live births (Department of Health, 2015).

The incidence of LBW in Padang City in 2014 was $297(1.7 \%)$ of 17,033 total live births. This number is grouped by gender.Of 8,602 live-born infants, 165 infants $(1.9 \%)$ and from 8,431 live baby infants, 132 babies (2\%) were born with LBW (Department of Health, 2015).

LBW prevention efforts can be done in various ways, one of them is by detecting the presence of risk factors associated with the occurrence of LBW and supervise to minimize the impact of these factors.Based on the description and data above, the authors are interested to examine the fator of mothers who are associated with LBW babies treated in Dr.M. Djamil Padang.

\section{METHODS}

Quantitative research withcase controlapproach.The subjects of the study were the mother of the LBW infant being treated at Dr.M. Djamil Padang as many as 36 respondents (cases), and mothers of infants who were treated with other diseases as much as 36 respondents (control) from July to mid September 2017 taken byConsecutive Sampling.Data collection was done by filling out questionnaires, observationof medical record data, and measurement of upper arm circumference. 
III. RESULTS

Table 1. Frequency Distribution of LBW Infants Treated at Dr.M. Djamil Padang Period July - Mid Se ptember 2017

\begin{tabular}{ccc}
\hline LBW & $\begin{array}{c}\text { Frequency } \\
(\mathbf{n = 3 6 )}\end{array}$ & Percentage (\%) \\
\hline BB Born & & \\
1500-2499 grams & 32 & $88.9 \%$ \\
1000-1500 grams & 4 & $11.1 \%$ \\
\hline Pregnancy Age & 35 & \\
<37 weeks & 1 & $97.2 \%$ \\
$\geq 37$ weeks & & $2.8 \%$ \\
\hline Referral Origin & & \\
Come Alone & 9 & $25.0 \%$ \\
Clinic / Private Practice & 1 & $2.8 \%$ \\
Regional Public Hospital / & 26 & $72.2 \%$ \\
Hospital Type B, C & & \\
Place of Birth & & \\
Clinic / Private Practice & 2 & $5.6 \%$ \\
Regional Public Hospital / & 11 & $30.6 \%$ \\
Hospital Type B, C & & \\
Dr.M. Djamilhospital & 23 & $63.9 \%$ \\
\hline Based On table1 & & \\
\hline
\end{tabular}

Based on table1 above, it can be seen that from 36 respondents who have babies BBLR, the majority of babies born with weight $1500-2499$ gram that is as many as 32 people $(88.9 \%)$, as many as 35 infants $(97.2 \%)$ born at gestation <37 weeks, 26 respondents $(72.2 \%)$ were referred from Regional Public Hospital / Hospital Type B, C, and 23 respondents (63.9\%) gave birth at Dr.M. Djamil Padang.

Table2.Independent Variable Frequency Distribution of LB W Infants treated at Dr.M. Djamil Padang Period July - Mid September 2017

\begin{tabular}{|c|c|c|c|c|}
\hline \multirow[b]{2}{*}{ Independent Variables } & \multicolumn{2}{|c|}{ Case } & \multicolumn{2}{|c|}{ Control } \\
\hline & $\mathbf{f}$ & $\%$ & $\mathbf{f}$ & $\%$ \\
\hline \multicolumn{5}{|l|}{ Mother Age } \\
\hline$<20 />35$ years & 21 & 58.3 & 8 & 22.2 \\
\hline 20-35 y ears old & 15 & 41.7 & 28 & 77.8 \\
\hline \multicolumn{5}{|l|}{ Maternal Nutrition } \\
\hline Status & 15 & 41.7 & 3 & 8.3 \\
\hline Bad & 21 & 58.3 & 33 & 91.7 \\
\hline \multicolumn{5}{|l|}{ Good } \\
\hline \multicolumn{5}{|l|}{ Parity } \\
\hline Primipara & 17 & 47.2 & 10 & 27.8 \\
\hline Multipara & 5 & 13.9 & 15 & 41.7 \\
\hline Grandemultipara & 14 & 38.9 & 11 & 30.6 \\
\hline \multicolumn{5}{|l|}{ Pregnancy Distance } \\
\hline At risk & 8 & 22.2 & 2 & 5.6 \\
\hline Not at Risk & 28 & 77.8 & 34 & 94.4 \\
\hline \multicolumn{5}{|l|}{ Medical Disease } \\
\hline There is & 32 & 88.9 & 21 & 58.3 \\
\hline There is no & 4 & 11.1 & 15 & 41.5 \\
\hline \multicolumn{5}{|l|}{ Type of Gestation } \\
\hline Gemelli & 2 & 5.6 & 0 & 0.00 \\
\hline Single & 34 & 94.4 & 36 & 100.0 \\
\hline
\end{tabular}

Based on table2above it can be seen that the respondents who have babies BBLR (case group) more at the age of risk ( $<20 />35$ years) as many as 21 respondents $(58,3 \%)$, while in the control group more at age not risk as much as 28 respondents $(77,8 \%)$.Maternal nutrition status was in good category as many as 21 respondents $(58,3 \%)$ in case group and 33 respondents $(91,7 \%)$ in control group.

Parity most respondents in the case group that is primiparas many as 17 respondents $(47,2 \%)$, whereas in the control group at most that multipara many as 15 respondents $(41.7 \%)$. The most frequent gestational distance was no risk, 28 respondents $(77,8 \%)$ in the case group and 34 respondents in the control group (94.4\%).The majority of respondents in the case group suffered one or more medical illnesses as many as 32 respondents $(88,9 \%)$, and 21 respondents $(58.3 \%)$ in the control group.Most respondents had single pregnancy, 34 respondents $(94,4 \%)$ in the case group, while in the control group all respondents had single pregnancy, 36 respondents $(100.0 \%)$.

\section{MotherAge Relationshipwith Infants LB W Table3. MotherAge Re lationshipwith Infants LB W}

\begin{tabular}{|c|c|c|c|c|c|c|c|c|}
\hline \multirow{3}{*}{$\begin{array}{c}\text { Mother } \\
\text { Age }\end{array}$} & \multicolumn{4}{|c|}{ LB W } & \multirow{2}{*}{\multicolumn{2}{|c|}{ amount }} & \multirow{2}{*}{$\begin{array}{c}\mathrm{X} 2 / \\
(p- \\
\text { value })\end{array}$} & \multirow{2}{*}{$\begin{array}{c}\text { OR / } \\
(95 \% \\
\text { CI })\end{array}$} \\
\hline & \multicolumn{2}{|c|}{ Yes } & \multicolumn{2}{|c|}{ No } & & & & \\
\hline & f & $\%$ & f & $\%$ & f & $\%$ & \multirow{3}{*}{0.004} & \multirow{3}{*}{$\begin{array}{c}4,900 \\
(1,753- \\
13,695)\end{array}$} \\
\hline At risk & 21 & 72.4 & 8 & 27.6 & 29 & 100.0 & & \\
\hline $\begin{array}{l}\text { Not at } \\
\text { Risk }\end{array}$ & 15 & 34.9 & 28 & 65.1 & 43 & 100.0 & & \\
\hline Total & 36 & 50.0 & 36 & 50.0 & 72 & 100.0 & & \\
\hline
\end{tabular}

Table 3 showsthat of 36 respondents who have LBW infants at the most risky age group were 21 respondents (72.4\%) compared to non-risky age of 15 respondents (34.9\%). Of the 36 respondents who did not have LBW infants at the most risky age group were 28 respondents (65.1\%) compared to the risky age of 8 respondents $(27.6 \%)$. Based on the statistical test was obtained $p$-value $<0,05(p=0.004)$, meaning that there is a significant correlation between maternal age with LBW infants who were treated at the Dr.M. Djamil PadangHospital.From the analysis results also obtained the value $\mathrm{OR}=$ 4,900 , meaning that mothers who are at risk of age have a chance of 4 , 9times giving birth to babies with LBW. 


\begin{tabular}{|c|c|c|c|c|c|c|c|c|}
\hline \multirow{3}{*}{$\begin{array}{c}\text { Materna } \\
\text { l } \\
\text { Nutritio } \\
\text { n Status }\end{array}$} & \multicolumn{4}{|c|}{ LB W } & \multicolumn{2}{|c|}{ amount } & \multirow{2}{*}{$\begin{array}{c}\mathrm{X} 2 / \\
(p- \\
\text { value } \\
)\end{array}$} & \multirow{2}{*}{$\begin{array}{c}\text { OR / } \\
(\mathbf{9 5 \%} \\
\text { CI })\end{array}$} \\
\hline & \multicolumn{2}{|c|}{ Yes } & \multicolumn{2}{|c|}{ No } & & & & \\
\hline & f & $\%$ & f & $\%$ & f & $\%$ & \multirow{5}{*}{0.003} & \\
\hline \multirow[t]{2}{*}{$\mathrm{Bad}$} & 1 & 83. & 3 & 16. & 1 & 100. & & 7,857 \\
\hline & 5 & 3 & & 7 & 8 & 0 & & (2.027- \\
\hline \multirow[t]{2}{*}{ Good } & 2 & 38. & 3 & 61. & 5 & 100. & & 30,459 \\
\hline & 1 & 9 & 3 & 1 & 4 & 0 & & ) \\
\hline \multirow[t]{2}{*}{ Total } & 3 & 50. & $\overline{3}$ & 50. & 7 & 100. & & \\
\hline & 6 & 0 & 6 & 0 & 2 & $\mathbf{0}$ & & \\
\hline
\end{tabular}

Table 4 showsthat of 36 respondents who have babies BBLR, most of the respondents have malnutrition status $(83.3 \%)$, and there are $38.9 \%$ of respondents have good nutritional status.In the group of respondents who did not have a baby of low birth weight, the percentage of respondents who have a good nutritional status more $(61,1 \%)$ is compared with poor nutritional status $(16.7 \%)$.Based on the statistical test was obtained $p$-value $<0,05(p=0.003)$, meaning that there is a significant relationship between the nutritional status of mothers with LBW babies were treated at the Dr.M. Djamil PadangHospital.From the analysis results also obtained the value $\mathrm{OR}=7,857$, meaning that mothers who have bad nutritional status have 7 , 8times give birth to babies with LBW.

\begin{tabular}{|c|c|c|c|c|c|c|c|}
\hline \multirow{3}{*}{ Parity } & \multicolumn{4}{|c|}{ LBW } & \multirow{2}{*}{\multicolumn{2}{|c|}{ amount }} & \multirow{3}{*}{$\begin{array}{c}\mathrm{X} 2 / \\
(p- \\
\text { value } \\
)\end{array}$} \\
\hline & \multicolumn{2}{|c|}{ Yes } & \multicolumn{2}{|c|}{ No } & & & \\
\hline & $\mathbf{f}$ & $\%$ & $\mathbf{f}$ & $\%$ & $\mathbf{f}$ & $\%$ & \\
\hline Primipara & $\begin{array}{l}1 \\
7\end{array}$ & $\begin{array}{c}63 . \\
0\end{array}$ & $\begin{array}{l}1 \\
0\end{array}$ & $\begin{array}{r}37 . \\
0\end{array}$ & $\begin{array}{l}2 \\
7\end{array}$ & $\begin{array}{c}100 . \\
0 .\end{array}$ & 0.028 \\
\hline Multipara & 5 & 25. & 1 & 75. & 2 & 100. & \\
\hline Grandemultipar & 1 & 0 & 5 & 0 & 0 & 0 & \\
\hline $\mathrm{a}$ & 4 & 56. & 1 & $\begin{array}{r}44 . \\
0\end{array}$ & $\begin{array}{l}2 \\
5\end{array}$ & $\begin{array}{c}100 . \\
0 .\end{array}$ & \\
\hline Total & $\begin{array}{l}3 \\
6\end{array}$ & $\begin{array}{c}50 . \\
0\end{array}$ & $\begin{array}{l}3 \\
6\end{array}$ & $\begin{array}{c}50 . \\
0\end{array}$ & $\begin{array}{l}7 \\
2\end{array}$ & $\begin{array}{c}100 . \\
0\end{array}$ & \\
\hline
\end{tabular}

Table 5 showsthat of 36 respondents who have LBW infants at most primiparous mothers, 17 respondents $(63.0 \%)$, and at least 5 multipara mothers $(25.0 \%)$. While in the group of respondents who did not have the most LBW infants in the multiparous mother were 15 respondents $(75.0 \%)$, and at least 10 primiparous mothers $(37.0 \%)$. Based on the statistical test was obtained $p$-value $<0,05(p=0.028)$, meaning that there is a significant relationship between parity with LBW infants who were treated at the Dr.M. Djamil PadangHospital.

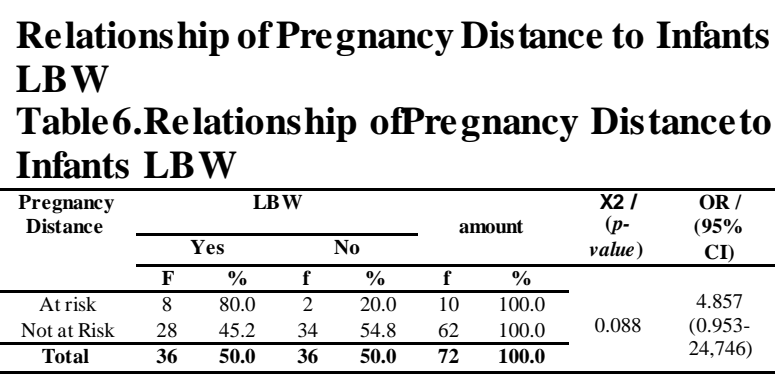

Table 6 showsthat of 36 respondents who had a BBLR baby, 28 respondents (45.2\%) had a non-risk pregnancy distance, and 8 respondents $(80.0 \%)$ had a risky gestational distance. Whereas in the group of respondents who did not have BBLR babies, 34 respondents $(54,8 \%)$ had a non-risk pregnancy distance, and 2 respondents $(20.0 \%)$ had a risky gestational distance.From the statistical test results obtained $\mathrm{p}$-value $>0,05(\mathrm{p}=0.088)$, meaning there is no relationship between the distance of pregnancy with LBW babies treated in Dr.M. Djamil Padang.

\section{Relationship of Mother's Medical Disease with Infants LB W}

Table7.Relationshipof Mother's Medical Dise as e with Infants LB W

\begin{tabular}{|c|c|c|c|c|c|c|c|c|}
\hline \multirow{4}{*}{$\begin{array}{l}\text { Mother' } \\
\text { s } \\
\text { Medical } \\
\text { Disease }\end{array}$} & \multicolumn{4}{|c|}{ LB W } & \multicolumn{2}{|c|}{ amount } & \multirow{3}{*}{$\begin{array}{c}\mathrm{X} 2 / \\
(p- \\
\text { value } \\
)\end{array}$} & \multirow{3}{*}{$\begin{array}{c}\text { OR / } \\
(95 \% \\
\text { CI })\end{array}$} \\
\hline & \multicolumn{2}{|c|}{ Yes } & \multicolumn{2}{|c|}{ No } & & & & \\
\hline & & & & & & & & \\
\hline & f & $\%$ & f & $\%$ & f & $\%$ & & \\
\hline There is & $\begin{array}{l}3 \\
2\end{array}$ & $\begin{array}{c}60 . \\
4\end{array}$ & $\begin{array}{l}2 \\
1\end{array}$ & $\begin{array}{c}39 . \\
6\end{array}$ & $\begin{array}{l}5 \\
3\end{array}$ & $\begin{array}{c}100 . \\
0\end{array}$ & 0.007 & $\begin{array}{c}5,714 \\
(1,666-\end{array}$ \\
\hline $\begin{array}{c}\text { There is } \\
\text { no }\end{array}$ & 4 & $\begin{array}{c}21 . \\
1\end{array}$ & $\begin{array}{l}1 \\
5\end{array}$ & $\begin{array}{c}78 . \\
9\end{array}$ & 1 & $\begin{array}{c}100 . \\
0\end{array}$ & & $\begin{array}{c}19,602 \\
)\end{array}$ \\
\hline Total & $\begin{array}{l}3 \\
6\end{array}$ & $\begin{array}{c}\text { 50. } \\
0\end{array}$ & $\begin{array}{l}3 \\
6\end{array}$ & 50. & $\begin{array}{l}7 \\
2\end{array}$ & 100. & & \\
\hline
\end{tabular}

Table 7 shows thatof 36 respondents who have LBW infants suffered the most one or more medical illnesses, 32 respondents $(60.4 \%)$ compared to 4 respondents $(21.1 \%)$. While in the group that did not have baby BBLR the number of respondents suffering from medical illness is 21 respondents $(39,6 \%)$. Based on the statistical test was obtained $\mathrm{p}$-value $<0,05(\mathrm{p}=0.007)$, meaning that there is a significant correlation between maternal medical disease with low birth weight infants who were treated at the Dr.M. Djamil PadangHospital.From the analysis results also obtained the value $\mathrm{OR}=5.714$, meaning that mothers who suffer one or more medical diseases have a chance of 5 times giving birth to babies with LBW. 


\section{Relationship Type of Gestation with Baby LBW}

Table 8.RelationshipType of Gestationwith Baby LB W

\begin{tabular}{|c|c|c|c|c|c|c|c|}
\hline \multirow{3}{*}{$\begin{array}{c}\text { Type of } \\
\text { Gestation }\end{array}$} & \multicolumn{4}{|c|}{ LBW } & \multicolumn{2}{|c|}{ amount } & \multirow{2}{*}{$\begin{array}{c}\mathrm{X} 2 / \\
(p- \\
\text { value })\end{array}$} \\
\hline & \multicolumn{2}{|c|}{ Yes } & \multicolumn{2}{|c|}{ No } & & & \\
\hline & $\mathbf{f}$ & $\%$ & $\mathbf{f}$ & $\%$ & f & $\%$ & \\
\hline Gemelli & 2 & 100.0 & 0 & 0.0 & 2 & 100.0 & \\
\hline Single & 34 & 48.6 & 30 & 51.4 & 70 & 100.0 & 0.493 \\
\hline Total & 36 & 50.0 & 36 & 50.0 & 72 & 100.0 & \\
\hline
\end{tabular}

\section{DISCUSSION}

\section{MotherAge Relationshipwith Infants LBW}

The result of bivariate analysis showed thatthere was asignificantcorrelation between maternal age and LBW infant with $p$ value $<0,05(p=0,004)$.

The results of this study are in line with Demelash et al (2015) study in Ethiopia that there is a significant relationship between maternal age and the occurrence of LBW with $p$ value $=<0.001$ and $\mathrm{OR}=3.1$, meaning that mothers at risky age have a 3.1 chance of giving birth babies with LBW.Likewise with research conducted Chaman et al, (2013) in Iran which states that there is a significant relationship between maternal age at risk with the incidence of LBW with $p$-value $=0.01$. However, this result differs from Mahayana research (2015) in Padang which states there is no relationship betweenmaternalagewith the incidence of BBLR with $p$-value $=0.713$.

Based on the results of this study, the percentage obtained showed thatmaternalage isclosely related to the occurrence of LBW.This is related to the maturity of the maternal reproductive organs for inadequate pregnancy, decreased maternal health conditions, and reduced egg quality that will affect the growth and development of the fetus, leading to complications, and preterm delivery resulting in low birth weight infants.

\section{Relation of Nutritional Status with Infants LBW}

Based on statistical test foundthat there is a significant relationship between maternal nutritional status and baby with LBWp-value $<0$, 05 $(p=0.003)$.

The result of this research is not in line with Mahayana research (2015) in Padang which
Table 8 showsthat of 36 respondents who had babies BBLR, 34 respondents $(48.6 \%)$ had a single pregnancy, and 2 respondents $(100.0 \%)$ had a gemelli pregnancy. While in the group of respondents who did not have BBLR infants, 36 respondents $(51,4 \%)$ had a single pregnancy. The results of statistical tests can not be performed because they do not meet the requirements of $c h i$ squaretest, but there is a tendency that mothers who have gemelli pregnancy have a high risk factor to give birth to LBW babies.

states that there is no correlation between maternal nutritional status and the occurrence of $\mathrm{LBW}$ with $p$-value $=0,256$, and the result of this research is not in line with Nurfitria research (2016) in Sukorejo, Ponorogo which states that the nutritional status between mothers who have babies BBLR and those not, is not significantly different $(p=0.189)$, meaning there is no relationship between maternal nutritional status and the occurrence of LBW. Yulizawati et al (2016), states that every woman should prepare well since the preconception and know when the occurrence of conception so that can prepare pregnancy well and produce quality generation. Improving nutritional status since preconception time is one of the things that need to be prepared for pregnancy to run normally and babies born not LBW.

Mothers who have malnutrition status can result in nutritional needs for growth and development of the fetus is not sufficient.Poor maternal nutritional statuswillalsoaffect the health condition of the mother, which can trigger the occurrence of LBW (Sulystiawati, 2009). This theory is in line with the results of research that found that the percentage of mothers who have babies BBLR more. So it can be stated that the maternal nutritional statuswillaffect the process of growth and development of the fetus and outcome of pregnancy.

\section{Parity Relationships with Infants LB W}

Based on the statistical test showedthat there is a significant relationship betweenparity with LBW babies with $p$-value $<0,05(p=0.028)$.

This result is in line with Nurfitria research (2016) in Sukorejo, Ponorogo which states that there is a significant relationship between parity with the occurrence of LBW with $p$-value= 0.003.Mothers who have given birth more than 3 times can experience decreased reproductive 
health so that the risk to the mother and fetus, one of them is LBW.While the first mothers of pregnancy and childbirth are also at risk of giving birth to LBW infants because the risk is reinforced by the presence of other risk factors that trigger the mother to deliver babies with LBW such as immature reproductive organs, maternal age, nutritional status, and medical illness or complications suffered by the mother (Sumarah, 2008).The results of this study inaccordance with thetheory that the percentage of mothers who have babies BBLR more in primipara and grandemultipara mothers.

\section{Re lations hip of Pre gnancy Distance to Infants LBW}

Based on the statistical test showedthatthereis nosignificant relationship betweendistance of pregnancy with baby $\mathrm{LBWp}$ value $>0,05(p=0,088)$.

The result of this research is different with Nurfitria research (2016) in Sukorejo, Ponorogo, which stated that pregnancy spacing in mothers who have LBW infants with no LBW babies is significantly different $(p=0.003)$, meaning that there is a significant relationship between pregnancy distance and LBW incidence.The distance of pregnancy is related to the readiness of the reproductive organs to re-accept implantation of the conception and reproductive process of pregnant and post-pregnant reproductive organs.

\section{Relationship of Mother's Medical Disease with Infants LB W}

Based on statistical test foundthat there is a significant relationship betweenmaternal medical illness with baby LBW $p$-value $<0,05(p=0,007)$.

This study is in line with research Sutan et al (2014) in Kuala Lumpur, Malaysia which states that hypertension has a significant relationship with the incidence of LBW.Mothers with essential hypertension, gestational hypertension, preeclampsia or eclampsia, 4, 5times more likely to deliver babies with LBW.Jin (2011) in Jama Patient Page states that the occurrence of LBW is caused by a chronic maternal medical condition one of them is high blood pressure. However, this study differs from Mahayana research (2015) in Padang which states there is no relationship between maternal medical illness with the incidence of LBW ( $p=0.661)$.

Maternal health conditions during pregnancy affect the growth and development of the fetus.Medical diseases that may be associated with LBW occurrences studied in this study are essential hypertension, gestational hypertension, preeclampsia, eclampsia, placenta previa, placental abruption, premature rupture of membranes, cardiovascular disease, diabetes mellitus, tuberculosis, and HIV.Pregnant women may suffer from one or more of the several diseases that can cause the baby to be born with LBW.

\section{Relationship Type of Gestation with Baby LB W}

The results of statistical tests can not be performed because they do not meet the requirements of chi squaretest, but there is a tendency that mothers who have gemelli pregnancy have a high risk factor to give birth to LBW babies. Mahayana research results (2015) in Padang which states there is no relationship between multiple pregnancy / type of gestation with the incidence of BBLR $(p=0.072)$.

The multiple pregnancy relationship with the occurrence of LBW is associated with excessive uterine distention resulting in premature labor.Multiple pregnancies also lead to nutritional deficiencies in the fetus because the fetus requires more nutrients than pregnancy with single gestation, hydramnios, and excessive uterine muscle retraction that leads to other complications such as PE / E and placental abruption which risk the baby born with LBW (Cunningham et al., 2012).

\section{CONCLUSION}

There was a relationship between maternal age at risk, poor nutritional status, parity, and maternal medical illness with LBW infants, and there was a tendency for gestational relationship (gemelli) with LBW, but there was no relationship between pregnancy spacing and LBW.Pregnant women are expected to pay attention and improve their nutrition since adolescence, preconception, and during pregnancy, and always performregular and periodicantenatal careto health workers to keep the mother's pregnancy normal and any possibility of complications or the existence of factors can trigger the occurrence of LBW can be detected early. 


\section{REFERENCES}

Chaman, R., M. Amiri, M. Raei, M. E. Ajami, A. Sadeghian, A. Khosravi. 2013. Low Birth Weight and Its Related Risk Factors in Northeast Iran. Irianian Journal of Pediatrics.http://ijp.tums.ac.ir. 16 April 2017 (13:02)

Cunningham, F. G., Leveno, Bloom, Hauth, Rouse, Sponge. 2010. Williams Obstetrics. $23^{\text {rd }}$ Edition. $1^{\text {st }}$ Volume. McGraw-Hill Companies, Inc. TerjemahanPendit, B. U. 2012. Obstetri Williams. Edisi 23. Volume 1.EGC. Jakarta

2010. Williams Obstetrics. 23 $3^{\text {rd }}$ Edition. $2^{\text {nd }}$ Volume. McGraw-Hill Companies, Inc. TerjemahanPendit, B. U. 2012. Obstetri Williams. Edisi 23.Volume 2.EGC. Jakarta

Dahlan, $\quad$ M. $2011 . \quad$ S. BesarSampeldan Cara PengambilanSampeldalamPenelitianKedokterandanKesehatan.Edisi 3.SalembaMedika. Jakarta

Demelash, H., A. Motbainor, D. Nigatu, K. Gashaw, and A. Melese. 2015. Risk Factors for Low Birth Weight in Bale Zone Hospitals, South-East Ethiopia: A Case-Control Study. BMC Pregnancy and Childbirth.http://creativecommons.org/licenses/by/4.0/. 16 April 2017 (12:15)

DinasKesehatanProvinsiSumbar. 2015. ProfilKesehatan 2014 Provinsi Sumatera Barat.DinkesProvinsiSumbar. Padang

England, C. 2009. Infants With Low Birth Weight Healthy. In: D. M. Fraser, and M. A. Cooper, eds. Myles Textbook for Midwives. 14 $4^{\text {th }}$ Edition. Elsevier Limited. Oxford, United Kingdom. TerjemahanRahayu, S., dan L. Mahmudah. 2009. Myles: BukuAjarBidan. Edisi 14.EGC. Jakarta

Hall, J. E. 2011. Guyton and Hall Textbook of Medical Physiology.Twelfth Edition. Saunders Elsevier Inc. TerjemahanWidjajakusumah, M. D. 2014. Guyton dan Hall: Buku Ajar FisiologiKedokteran. EdisiKeduabelas. Elsevier Pte. Ltd. Singapore

Hasanah, N. 2010.Faktor-Faktor yang BerhubungandenganKejadianBayiBeratLahirRendah (BBLR) di Ruang BBRT RSUP Dr. Kariadi Semarang Tahun 2010.abdi_husada@ yahoo.co.id. 07 September 2017 (10:44)

IkatanDokterAnak Indonesia. 2013. Best Practices in Pediatrics. IDAI. Jakarta

Ikenna et al,. 2015. Maternal Risk Factors Associated with Low Birth Weight Neonates: A Multi-Center, Cross Sectional Study in A Developing Country. Journal of Neonatal Biology.http://dx.doi.org/10.4172/2167-0897.1000190. 16 April 2017 (13:05)

Jin, J. 2011 Babies with Low Birth Weight.Jama Patient Page.http://jamanetwork.com/pdfaccess.ashx?url=/data/journals/jama/931940/. 16 April 2017 $(12: 05)$

Joshi, H. S., Srivastava, P. C., Agnihotri, A. K., Joshi, M. C., Chandra, S., and Mahajan, V. 2014.Risk Factor for Low Birth Weight (LBW) Babies and Medico-Legal Significance.J Indian Acad Forensic Med, 32 (3)

KementerianKesehatan RI. 2014. ProfilKesehatan Indonesia Tahun 2013.Kemenkes RI. Jakarta 2014. InfoDATIN (Pusat Data danInformasiKementerianKesehatan RI): KondisiPencapaian

Program KesehatanAnak Indonesia. Kemenkes RI. Jakarta 2015. ProfilKesehatan Indonesia Tahun 2014.Kemenkes RI. Jakarta 2016. ProfilKesehatan Indonesia Tahun 2015.Kemenkes RI. Jakarta 2016. Data danInformasi 2015 "ProfilKesehatan Indonesia”. Kemenkes RI. Jakarta

Mahayana, S. A. S., E. Chundrayetti, danYulistini. 2015. FaktorRisiko yang BerpengaruhterhadapKejadianBeratBadanLahirRendah di RSUP Dr. M. Djamil Padang.JurnalKesehatan UNAND. http//jurnal.fk.unand.ac.id. 19 November 2016 (00:03)

Manuaba, I. A. C., I. B. G. F. Manuaba, dan I. B. G. Manuaba. 2010. IlmuKebidanan, PenyakitKandungan, dan KB untukPendidikanBidan. Edisi 2.EGC. Jakarta

Muchemi, O, M., E. Echoka, A. Makokha. 2015. Factors Associated With Low Birth Weight Among Neonates Born at Olkalou District Hospital, Central Region, Kenya. Pan African Medical Journal.http://www.panafrican-med-journal.com/content/article/20/108/full. .16 April 2017 $(12: 12)$

Notoatmodjo, S. 2003. PromosiKesehatandanPerilakuKesehatan.RinekaCipta. Jakarta

Nurfitria, U, N., 2016. Faktor-Faktor yang BerkaitandenganKejadianBeratBayiLahirRendah (BBLR) di Wilayah KerjaPuskesmasSukorejo, Ponorogo. 07 September 2017. (10:45) . 2010. MetodologiPenelitianKesehatan. RinekaCipta. Jakarta 
Pantiawati, I. 2010. Bayidengan BBLR (BeratBadanLahirRendah).NuhaMedika. Yogyakarta

Prawirohardjo, S. $2008 . \quad$ IlmuKebidananSarwonoPrawirohardjo. $\quad$ P.

P. T.

BinaPustakaSarwonoPrawirohardjo. Jakarta

2010. IlmuKebidananSarwonoPrawirohardjo. Edisi 4.CetakanKetiga. P. T.

BinaPustakaSarwonoPrawirohardjo. Jakarta

Proverawati, A dan C. I. Sulistyorini. 2010. BBLR (BeratBadanLahirRendah). NuhaMedika. Yogyakarta

Reflita. 2011. Faktor-Faktor yang BerhubungandenganKejadianBeratBadanLahirRendah. NersJurnalKeperawatan. 07 September 2017 (10:48)

Salmah, Rusmiati, Maryanah, Susanti. 2006. AsuhanKebidanan Antenatal. EGC. Jakarta

Sofian, A. 2011.RustamMochtarSinopsisObstetri: ObstetriFisiologi, ObstetriPatologi. Edisi 3.Jilid 1.EGC. Jakarta

Sulistyawati, A. 2009.AsuhanKebidananpadaMasaKehamilan.SalembaMedika. Jakarta

Sumarah, Y. N. 2008. AsuhanKebidananpadaIbuBersalin.Fitramaya. Yogyakarta

Sutan, R., M. Mohtar, A. N. Mahat, dan A. M. Tamil. 2014. Determinant of Low Birth Weight Infants: A Matched Case Control Study. http:/www.scirp.org/journal/ojpmhttp://dx.doi.org/10.4236/ojpm.2014.43013. 14 November $2016(19: 59)$

United Nations Children's Fund. 2004. UNICEF Data: Monitoring the Situation of Children and Women. Undernourishment in the Womb can Lead to Diminished Potential and Predispose Infants to early death. https://data.unicef.org/topic/nutrition/low-birthweight/\#. 14 Mei 2017 (12:56)

. 2016. Low Birth Weight: Country, Regional, and Global Estimate. UNICEF. New York

United Nations Development Programme (UNDP). 2015. Human Development Report 2015: Work for Human

Development. http//hdr.undp.org/sites/default/files/2015_human_development_report.pdf. 24 Januari 2017 (23:02)

Varney, H., J. M. Kriebs, dan G. L. Gegor. 2004. Varney's Midwifery. $4^{\text {th }}$ Edition. $1^{\text {st }}$ Volume. Jones and Bartlett Publishers, Inc. TerjemahanLusiyana, A., L. Mahmudah, G. Trisetyati, dan W. Eka. 2006. Buku-Ajar AsuhanKebidanan. Edisi 4. Volume 1.EGC. Jakarta

2004. Varney's Midwifery. $4^{\text {th }}$ Edition. $2^{\text {nd }}$ Volume. Jones and Bartlett Publishers, Inc. TerjemahanMahmudah, L., dan G. Trisetyati. 2007. Buku-Ajar AsuhanKebidanan. Edisi 4.Volume 2.EGC. Jakarta

Walyani, E. S. 2014. Materi Ajar LengkapKebidananKomunitas: Teori, Aplikasi, danAskeb. CetakanPertama. PUSTAKABARUPRESS. Yogyakarta

World Health Organization (WHO). 2012. Health Statistics and Information Systems.http://www.who.int/healthinfo/statistics/indmaternalmortality/en/. 19 November 2016 $(19: 20)$

. 2014. WHA Global Nutrition Targets 2025: Low Birth Weight Policy Brief. http:/www.who.int/nutrition/topics/globaltargets_lowbirthweight_policybrief.pdf. 19 November $2016(19: 24)$

. 2016. Newborn: Reducing Mortality. http//www.who.int/mediacentre/factsheets/fs333/en/. 14 Mei 2017 (06:55)

Yulizawati, Nurdiyan. A., Bustami, L. E. S., Iryani, D dan Insani, A. A. 2016. ImplementasiKonsepSiklusMenstruasiPadaKonselingSkrening Premarital.Journal of Midwifery. Vol 1. No 2(2016) 